\title{
Isolasi dan Identifikasi Bakteri Endofit Beberapa Jenis Pohon Berhabitat Basah
}

\author{
Isolation and Identification of Endophytic Bacteria of Some Wet Habitat Trees
}

\section{Ckrisna D. Nuruwe, Johan M. Matinahoru*, Miranda H. Hadijah}

\author{
Program Studi Kehutanan, Fakultas Pertanian Universitas Pattimura, Jl. Ir. M. Putuhena, Kampus Poka Ambon, \\ 97233 Indonesia \\ *E-mail Penulis Korespondensi: johan.matinahoru@faperta.unpatti.ac.id
}

Tanggal submisi: 15 Mei 2020; Tanggal penerimaan: 15 Juni 2020

\begin{abstract}
The purpose of this study was to determine the macroscopic and microscopic characteristics of endophytic bacteria that live in the root and leaf tissue of several wet habitat trees, such as: kayu marsegu (Anthocephalus cadamba), ketapang hutan (Terminalia copelandii) and kayu burung (Elaeocarpus ganitrus). This study shows that the results of microscopic identification of 20 samples of bacterial isolates, there are only 11 samples of endophytic bacteria that live in the root and leaf tissue of tree samples. Furthermore, based on microscopic identification with the Gram Staining Method, it was found that there were 17 samples of endophytic bacterial isolates categorized into gram-negative (-), namely: DM1, DM3, DM4, AM1, AM2, AM3, AM4, DKH2, DKH3, DKH4, AKH1, AKH2, AKB1, $A K B 2, A K B 3, D K B 3$, and DKB4. While 3 other bacterial isolate samples were classified into gram-positive (+), namely: AKH3, AKH4, and AKB4. Based on observations with a microscope with 1000 times the magnification size, all bacteria isolates were categorized as a rounded bacterial group, and therefore they are classified as genera Monococcus, Staphylococcus, and Streptococcus. The study also found that all three genera of bacteria have the ability to live in root and leaf tissue, even though the tree habitat is in a long-wet condition.
\end{abstract}

Keywords: endophytic bacteria, isolation, morphology, wet habitat trees

\section{ABSTRAK}

Tujuan dari penelitian ini adalah untuk menentukan karakteristik makroskopis dan mikroskopis dari bakteri endofit yang hidup di akar dan jaringan daun dari beberapa pohon habitat basah, seperti: kayu marsegu (Anthocephalus cadamba), ketapang hutan (Terminalia copelandii) dan kayu burung (Elaeocarpus ganitrus). Penelitian ini menunjukkan bahwa dari hasil identifikasi mikroskopis terhadap 20 sampel isolat bakteri, hanya ada 11 sampel bakteri endofit yang hidup di akar dan jaringan daun sampel pohon. Selanjutnya, berdasarkan identifikasi mikroskopis dengan Metode Pewarnaan Gram, ditemukan bahwa ada 17 sampel isolat bakteri endofit yang dikategorikan menjadi gram-negatif (-), yaitu: DM1, DM3, DM4, AM1, AM2, AM3, AM4, DKH2, DKH3, DKH4, AKH1, AKH2, AKB1, AKB2, AKB3, DKB3, dan DKB4. Sedangkan 3 sampel isolat bakteri lainnya digolongkan kedalam gram-positif (+), yaitu: AKH3, AKH4, dan AKB4. Berdasarkan pengamatan dengan mikroskop ukuran pembesaran 1000 kali, semua isolat bakteri dikategorikan sebagai kelompok bakteri bulat, dan oleh karena itu mereka diklasifikasikan sebagai genus Monococcus, Staphylococcus, dan Streptococcus. Studi ini juga menemukan bahwa ketiga genera bakteri memiliki kemampuan untuk hidup dalam jaringan akar dan daun, meskipun habitat pohon berada dalam kondisi basah yang lama.

Kata Kunci: bakteri endofit, isolasi, morfologi, pohon berhabitat basah

\section{PENDAHULUAN}

Beberapa jenis pohon hutan seperti kayu marsegu (Anthocephallus cadamba), ketapang hutan (Terminalia copelandii) dan kayu burung (Elaeocarpus ganitrus) mempunyai habitat untuk tumbuh dan berkembang adalah pada ekosistem hutan rawa atau lahan yang selalu tergenang disepanjang musim hujan. Keunikan dari jenis-jenis pohon ini adalah mempunyai kecepatan tumbuh yang luar biasa, misalnya rata-rata pertambahan ukuran diameter batang setiap tahun adalah 2-3 cm, dan mempunyai kemampuan untuk bertahan hidup dalam 
genangan air bisa lebih dari 3 bulan. Kondisi ini diduga ada pengaruh positif dari mikroba yang hidup didalam jaringan dari organ jenis-jenis pohon tersebut. Mikroba adalah makluk hidup ukuran sangat kecil (mikro) yang dapat hidup dan berkembang pada media apa saja, termasuk manusia, hewan dan tumbuhan. Secara umum makluk hidup yang tergolong mikroba adalah virus, bakteri dan cendawan. Mikroba yang hidup pada organisme hidup lain dapat berpengaruh positif maupun negatif. Mikroba yang berpengaruh positif terutama pada tumbuhan, seringkali disebut sebagai mikroba endofit. Secara umum mikroba endofit pada tumbuhan, dapat berperan sebagai penyedia unsur hara, pengendali hama dan penyakit serta membantu proses-proses metabolisme sekunder didalam sel tumbuhan (Stone et al., 2000). Hallman dan Berg (2006) mengemukakan bahwa bakteri endofit dapat menambah ketahanan tanaman terhadap berbagai jenis mikroba patogen dengan cara Induced Resistance System sehingga tanaman dapat tahan terhadap serangan penyakit. Selain itu, mikroba endofit juga mudah dikembangbiakan dan memiliki siklus hidup yang pendek, sehingga bisa menjadi salah satu sumber senyawa bioaktif penting untuk dikembangkan bagi tanaman.

Mikroba endofit berupa bakteri, cendawan dan virus hampir dapat dijumpai secara mudah pada kira-kira 300.000 spesies tanaman dimuka bumi ini. Bakteri, virus maupun cendawan endofit dapat hidup dan berkembang dalam satu inang tanaman. Cendawan endofit biasanya tumbuh dan berkembang pada permukaan organ tumbuhan dan kemudian hypanya dapat masuk kedalam jaringan organ tumbuhan inang, sedangkan bakteri endofit masuk kedalam tubuh tanaman pada saat penyerapan air dan unsur hara oleh akar tumbuhan, dan selanjutnya bakteri dapat ikut terangkut masuk kebagian organ tumbuhan yang lain, seperti: batang, daun, bunga maupun kotiledon (Strobel dan Daisy, 2003).

Di bidang pertanian kita mengenal padi sawah (Oryza sativa) sebagai tanaman pangan dan memiliki habitat untuk tumbuh dan berkembang secara baik pada lahan-lahan basah dengan lama genangan air dapat mencapai rata-rata 1-2 bulan. Hal ini berarti bakteri endofit yang hidup pada jenis-jenis pohon berhabitat basah seperti yang diteliti dalam penelitian ini dapat berpotensi untuk dipelajari lebih lanjut agar bermanfaat bagi pertumbuhan dan produksi tanaman padi. Pengembangan pupuk hayati untuk mengatasi polusi lingkungan akibat pupuk anorganik, dengan cara pengembangbiakan bakteri endofit dalam bentuk larutan biostimulan, akan menjadi cara yang penting untuk dilakukan. Hal ini karena petani lebih cenderung memakai pupuk kimia guna memperbaiki pertumbuhan dan produksi padi.

Penelitian ini menggunakan sampel berupa akar dan daun tumbuhan dari pohon marsegu, ketapang hutan dan kayu burung. Hal ini karena akar tumbuhan berfungsi sebagai penyerap air dan unsur hara bagi tumbuhan, dan daun berfungsi sebagai pusat fotosintesis tumbuhan. Oleh karena itu bakteri endofit yang hidup dan berkembang pada jaringan akar dan daun dari ketiga jenis pohon tersebut diatas sangat penting untuk diteliti.

Penelitian ini bertujuan untuk: 1) mengetahui karakteristik morfologi dari bakteri endofit pada beberapa jenis pohon berhabitat basah, seperti: kayu marsegu (Anthocephalus cadamba), ketapang hutan (Terminalia copelandii), dan kayu burung (Elaeocarpus ganitrus); dan 2) mengidentifikasi dan menentukan kelompok bakteri endofit yang bersimbiosis dengan jenis pohon berhabitat basah. Manfaat penelitian adalah sebagai data dan informasi dasar bagi pengembangan pupuk hayati yang ramah lingkungan terutama bagi tanaman pangan yang memiliki habitat tumbuh yang sama.

\section{BAHAN DAN METODE}

\section{Tempat dan Waktu Penelitian}

Penelitian ini dilakukan di Laboratorium Biokontrol Fakultas Pertanian dan Laboratorium Mikrobiologi Fakultas MIPA, Universitas Pattimura pada Agustus sampai dengan September 2019.

\section{Bahan dan Alat Penelitian}

Bahan tanaman yang diperlukan bagi penelitian ini adalah akar dan daun pohon marsegu, ketapang hutan dan kayu burung. Sedangkan bahan kimia yang digunakan bagi kegiatan analisis dan identifikasi bakteri endofit adalah TSA (Tryptic Soybroth Agar), akuades steril, alkohol $70 \%, \mathrm{NaOCl}$, nutrien agar Clorox $3 \%$, crystal violet, alkohol 95\%, larutan iodine, safranin, alumunium foil, kapas, kertas tisu, spiritus dan kertas label.

Peralatan yang digunakan adalah cawan petri, rak tabung reaksi, tabung reaksi, jarum ose, bunsen, mortar, pistil, gelas erlemeyer ukuran $250 \mathrm{ml}$, autoclave, laminar air flow, oven, timbangan analitik, pipet tetes, kaca pembesar, kaca preparat, dan mikroskop pembesaran $1000 \times$.

\section{Pelaksanaan Penelitian}

\section{Isolasi Bakteri Endofit}

Sampel akar dan daun kayu marsegu diambil di pulau Ambon, sedangkan sampel ketapang hutan dan kayu burung diambil di pulau Seram. Pada tiap jenis pohon dikumpulkan 4 sampel akar dan 4 sampel daun dengan berat rata-rata tiap sampel adalah $500 \mathrm{~g}$. Penelitian ini menggunakan 3 jenis pohon, sehingga jumlah keseluruhan sampel akar dan daun adalah 24 sampel untuk kegiatan pengamatan. Semua sampel tanaman dicuci dengan air mengalir sampai bebas dari kotoran, dan selanjutnya ditimbang masing-masing dengan berat $1 \mathrm{~g}$ dan di beri label kode seperti pada Tabel 1. 
Tabel 1. Kode, jenis dan jumlah sampel penelitian

\begin{tabular}{|c|c|c|c|c|}
\hline No. & Kode Sampel & Bagian Organ Pohon & Jenis Pohon & Jumlah Sampel \\
\hline 1 & DM1 & Daun & Kayu Marsegu & 1 \\
\hline 2 & DM2 & Daun & Kayu Marsegu & 1 \\
\hline 3 & DM3 & Daun & Kayu Marsegu & 1 \\
\hline 4 & DM4 & Daun & Kayu Marsegu & 1 \\
\hline 5 & AM1 & Akar & Kayu Marsegu & 1 \\
\hline 6 & AM2 & Akar & Kayu Marsegu & 1 \\
\hline 7 & AM3 & Akar & Kayu Marsegu & 1 \\
\hline 8 & AM4 & Akar & Kayu Marsegu & 1 \\
\hline 9 & DKH1 & Daun & Ketapang Hutan & 1 \\
\hline 10 & DKH2 & Daun & Ketapang Hutan & 1 \\
\hline 11 & DKH3 & Daun & Ketapang Hutan & 1 \\
\hline 12 & DKH4 & Daun & Ketapang Hutan & 1 \\
\hline 13 & AKH1 & Akar & Ketapang Hutan & 1 \\
\hline 14 & AKH2 & Akar & Ketapang Hutan & 1 \\
\hline 15 & AKH3 & Akar & Ketapang Hutan & 1 \\
\hline 16 & AKH4 & Akar & Ketapang Hutan & 1 \\
\hline 17 & DKB1 & Daun & Kayu Burung & 1 \\
\hline 18 & DKB2 & Daun & Kayu Burung & 1 \\
\hline 19 & DKB3 & Daun & Kayu Burung & 1 \\
\hline 20 & DKB4 & Daun & Kayu Burung & 1 \\
\hline 21 & AKB1 & Akar & Kayu Burung & 1 \\
\hline 22 & AKB2 & Akar & Kayu Burung & 1 \\
\hline 23 & AKB3 & Akar & Kayu Burung & 1 \\
\hline 24 & AKB4 & Akar & Kayu Burung & 1 \\
\hline
\end{tabular}

Keterangan: DM = Daun Kayu Marsegu, AM = Akar Kayu Marsegu, DKH = Daun Ketapang Hutan, AKH = Akar Ketapang Hutan, $\mathrm{DKB}=$ Daun Kayu Burung, AKB = Akar Kayu Burung

Selanjutnya sterilisasi bahan tanaman dilakukan dengan cara direndam dalam $\mathrm{NAOCl}$ selama 2 menit, kemudian direndam dengan alkohol $70 \%$ selama 1 menit, dan selanjutnya dibilas sebanyak 3 kali dengan aquades steril. Sebagai kontrol untuk memastikan bakteri yang diisolasi merupakan bakteri endofit, maka bagian akar dan daun tanaman digoreskan pada permukaan media TSA. Langkah berikut adalah sampel akar dan daun tanaman masing-masing dihaluskan dengan menggunakan mortal dan pistil, dan dilakukan penggerusan sampai sampel tanaman menjadi sangat halus, lalu tambahkan $10 \mathrm{ml}$ aquades steril. Kemudian dari hasil penggerusan, diambil $1 \mathrm{ml}$ dan dilakukan pengenceran berseri $10^{-1}$ sampai $10^{-4}$. Hasil pengenceran digoreskan pada media TSA dan diinkubasi selama 48 jam, kemudian koloni tunggal hasil isolasi dimurnikan dengan media NA (Nutrien Agar). Langkah akhir yaitu diinkubasi lagi selama 48 jam dan setelah itu koloni murni yang tampak pada masing-masing cawan petri diamati secara makro karakteristik morfologi bakteri yang meliputi: bentuk koloni, bentuk tepian elevasi, warna koloni, dan ukuran koloni.

\section{Identifikasi Bakteri Endofit}

Identifikasi bakteri endofit menggunakan dua metode yaitu cara makroskopis dan cara mikroskopis. Pengamatan cara makroskopis yaitu pengenalan morfologi koloni bakteri yang meliputi: bentuk koloni, bentuk tepian, elevasi, warna koloni dan ukuran koloni dengan menggunakan protokol Holt et al. (1994). Sedangkan pengamatan secara mikroskopis dilakukan dengan cara Pewarnaan Gram yaitu diamati jenis gram bakteri dan bentuk sel bakteri di laboratorium. Bakteri yang telah diisolasi dikultur dengan metode Goresan Kuadran pada media dan diinkubasi selama 48 jam. Kemudian siapkan kaca objek dan bersihkan dengan alkohol $70 \%$. Selanjutnya tambahkan air steril pakai pipet tetes di atas kaca objek dengan menggunakan teknik aseptis. Ambil sedikit bakteri menggunakan jarum ose, kemudian letakan pada tetesan air steril yang ada di atas kaca objek dan diaduk hingga merata sehingga preparat bakteri tidak mengumpul. Kemudian preparat dibiarkan sampai kering angin dan difiksasi di atas api bunsen agar bakteri menempel pada kaca objek, kemudian siap untuk diwarnai. Pewarnaan dimulai dengan menyiapkan zat-zat pewarna antara lain larutan cristal violet, lugol dan safranin, serta larutan hapusan 
etanol absolut atau alkohol 95\%. Berikan larutan Kristal Violet pada preparat dan diamkan selama 1 menit, kemudian bilas menggunakan aquades. Selanjutnya berikan larutan lugol pada preparat dan diamkan selama 2 menit, setelah itu dibilas dengan menggunakan aquades. Berikut diberikan larutan hapusan Etanol atau Alkohol 95\% dengan cara tetes demi tetes selama 30 detik sampai hasil tetesan tidak lagi terlihat ada warna biru yang luntur, lalu dibilas dengan aquades. Selanjutnya diberikan larutan safranin sebagai larutan pembeda terhadap warna Kristal Violet dan diamkan selama 30 detik, lalu dibilas lagi dengan aquades. Setelah itu preparat dikeringkan dengan kertas tisu, dan siap diamati dengan menggunakan mikroskop pembesaran 1000×. Untuk memperjelas hasil pengamatan, tambahkan minyak imersi ke atas preparat. Selanjutnya pewarnaan bakteri dilakukan untuk mengetahui sifatsifat gram dari kelompok bakteri gram-positif (+) dan bakteri gram-negatif (-).

\section{HASIL DAN PEMBAHASAN}

\section{Isolasi Bakteri Endofit}

Proses isolasi bakteri endofit dari 24 sampel akar dan daun pohon marsegu, ketapang hutan dan kayu burung dilakukan dengan menggunakan protokol Holt et al. (1994). Proses isolasi ini menghasilkan 20 isolat yang murni mengandung bakteri endofit. Langkah selanjutnya dilakukan pemurnian isolat dengan menggunakan media NA, dan diperoleh bahwa semua sampel akar ketiga jenis pohon mengandung bakteri endofit, sedangkan pada sampel daun pohon tidak semua sampel mengandung bakteri endofit seperti pada daun marsegu dan ketapang hutan masing-masing terdapat 1 sampel yang tidak mengandung bakteri endofit, dan juga pada sampel daun kayu burung terdapat 2 sampel yang tidak mengandung bakteri endofit.

\section{Identifikasi Makroskopis Bakteri Endofit}

Setelah ke 20 isolat bakteri endofit diinkubasi selama 48 jam dengan metode Goresan Kwadran maka tahap selanjutnya dilakukan karakterisasi morfologi (bentuk koloni, bentuk tepian elevasi, warna koloni dan ukuran koloni). Hasil identifikasi menunjukan bahwa hanya terdapat 11 isolat dengan karakteristik morfologi koloni yang sama atau mirip, seperti pada Tabel 2.

\section{Identifikasi Mikroskopis Bakteri Endofit}

Hasil uji karakteristik bakteri endofit dengan metode pewarnaan gram diperoleh ada kelompok bakteri gram-negatif dan gram-positif yang hidup pada ketiga jenis pohon. Bakteri gram-negatif merupakan bakteri yang dalam proses pewarnaan tidak bisa mempertahankan warna metil ungu, sedangkan bakteri gram-positif adalah bakteri yang jika dicuci dengan alkohol dapat mempertahankan warna ungu gelap. Hasil pengujian ini juga membedakan kedua kelompok bakteri berdasarkan struktur dinding selnya, dimana dinding sel bakteri gram-negatif lebih tipis dari pada dinding sel bakteri gram-positif. Dinding sel bakteri gram-negatif juga mempunyai tebal lapisan peptidoglikan antara 2-7 $\mathrm{nm}$ dan dilapisi oleh membran luar dengan tebal 7-8 nm. Hal ini karena bakteri gram-negatif mengandung banyak lipid dari pada bakteri gram-positif. Hasil pengujian juga menunjukan bahwa selama proses pewarnaan, pemberian alkohol terhadap bakteri gram-negatif menyebabkan tereaksinya lipid, sehingga memperbesar permebialitas dinding sel bakteri gram-negatif. Hal ini menyebabkan kompleks ungu kristal violet yang sudah masuk kedalam dinding sel sebelumnya dapat diekstraksi, sehingga bakteri gram-negatif menjadi kehilangan warna tersebut (Pelczar dan Chan, 1988).

Tabel 2. Hasil Identifikasi Karakteristik Makrokopis Bakteri Endofit Pada Jaringan Akar dan Daun Pohon Marsegu, Ketapang Hutan dan Kayu Burung.

\begin{tabular}{lllllll}
\hline No & Bentuk Koloni & BentukTepian & Elevasi & Warna Koloni & $\begin{array}{l}\text { Ukuran } \\
\text { Koloni }\end{array}$ & Kode Isolat \\
\hline 1. & Bundar & Licin & Timbul & Kuning & Sedang & DM1, DM3 \\
2. & Benang halus & Lekukan benang & Berbukit & Kuning & Titik & DM4 \\
3. & Bundar & Licin & Timbul & Kuning & Sedang & AM1, AM2, AM3, AM4 \\
4. & Bundar & Licin & Timbul & Kuning & Kecil & DKH2 \\
5. & Bundar & Licin & Datar & Putih & Kecil & DKH3 \\
6. & Filliform & Berombak & Berbukit & Kuning & Titik & DKH4 \\
7. & Bundar & Tak beraturan & Datar & Putih & Kecil & AKH1, AKH2 \\
8. & Bundar & Licin & Datar & Putih & Sedang & AKH3, AKH4 \\
9. & Bundar & Licin & Timbul & Kuning & Sedang & DKB3, DKB4 \\
10. & Bundar & Tak beraturan & Timbul & Putih susu & Sedang & AKB1, AKB2, AKB3 \\
11. & Filliform & Tak beraturan & Timbul & Kuning & Kecil & AKB4 \\
\hline
\end{tabular}

Keterangan: DM = Daun Kayu Marsegu, AM = Akar Kayu Marsegu, DKH = Daun Ketapang Hutan, AKH = Akar Ketapang Hutan, DKB $=$ Daun Kayu Burung, AKB = Akar Kayu Burung 
Tabel 3. Hasil Identifikasi Secara Mikroskopis Bakteri Endofit Pada Jaringan Akar dan Daun Pohon Marsegu, Ketapang Hutan, dan Kayu Burung

\begin{tabular}{|c|c|c|c|}
\hline No. & $\begin{array}{l}\text { Kode } \\
\text { Isolat }\end{array}$ & $\begin{array}{c}\text { Pewarnaan } \\
\text { Gram }\end{array}$ & Bentuk Sel \\
\hline 1. & DM1 & $(-)$ & Monococus \\
\hline 2. & DM3 & $(-)$ & Monococus \\
\hline 3. & DM4 & $(-)$ & Staphylococcus \\
\hline 4. & AM1 & $(-)$ & Monococcus \\
\hline 5. & AM2 & $(-)$ & Monococcus \\
\hline 6. & AM3 & $(-)$ & Monococcus \\
\hline 7. & AM4 & $(-)$ & Monococcus \\
\hline 8. & DKH2 & $(-)$ & Monococcus \\
\hline 9. & DKH3 & $(-)$ & Monococcus \\
\hline 10. & DKH4 & $(-)$ & Monococcus \\
\hline 11. & AKH1 & $(-)$ & Staphylococcus \\
\hline 12. & $\mathrm{AKH} 2$ & $(-)$ & Staphylococcus \\
\hline 13. & AKH3 & $(+)$ & Monococcus \\
\hline 14. & AKH4 & $(+)$ & Monococcus \\
\hline 15. & DKB3 & $(-)$ & Monococcus \\
\hline 16. & DKB4 & $(-)$ & Monococcus \\
\hline 17. & AKB1 & $(-)$ & Monococcus \\
\hline 18. & AKB2 & $(-)$ & Monococcus \\
\hline 19. & AKB3 & $(-)$ & Monococcus \\
\hline 20. & AKB4 & $(+)$ & Streptococcus \\
\hline
\end{tabular}

Keterangan: DM = Daun Kayu Marsegu, $\mathrm{AM}=$ Akar Kayu Marsegu, DKH = Daun Ketapang Hutan, AKH = Akar Ketapang Hutan, DKB = Daun Kayu Burung, $\mathrm{AKB}=$ Akar Kayu Burung

Hasil pewarnaan gram (+) dan gram (-) terhadap bakteri endofit pada jaringan akar dan daun pohon marsegu, ketapang hutan dan kayu burung diperoleh 17 isolat yang termasuk kedalam kelompok bakteri gramnegatif (-), yaitu: sampel dengan kode DM1, DM3, DM4, AM1, AM2, AM3, AM4, DKH2, DKH3, DKH4, AKH1, AKH2, DKB3, DKB4, AKB1, AKB2, dan AKB3, sedangkan 3 isolat lainnya termasuk dalam kelompok bakteri gram-positif (+), yaitu: sampel dengan kode AKH3, AKH4 dan AKB4.

Hasil pada Tabel 3 menunjukan bahwa terdapat 3 kelompok genus bakteri endofit yang hidup pada jaringan akar dan daun pohon marsegu, ketapang hutan dan kayu burung. Kelompok bakteri tersebut adalah genus Monococcus, Staphylococcus dan Streptococcus. Data tabel 3 juga memperlihatkan bahwa bakteri endofit genus Monococcus yang paling dominan menggunakan jaringan akar dan daun pohon marsegu, ketapang hutan dan kayu burung sebagai habitat untuk hidup dan berkembang. Sedangkan genus Staphylococcus hanya dijumpai hidup pada jaringan akar pohon ketapang hutan, dan juga dalam jumlah sedikit pada daun pohon marsegu. Genus Streptococcus hanya hidup pada jaringan akar kayu burung dan tidak ada pada akar dan daun pohon marsegu dan ketapang hutan. Bakteri-bakteri ini berperan penting dalam membantu membatasi jumlah serapan air oleh sel-sel akar rambut dari tanah untuk masuk ke selsel lain dari organ tumbuhan, terutama pada saat musim hujan dimana terjadi penggenangan habitat selama berbulan-bulan. Kelompok bakteri ini diduga hidup terutama pada jaringan akar yaitu pada saluran transfort air dan unsur hara, sehingga dapat membantu mengatur jumlah air yang harus melewati jalur apoplas dan simplas dari satu sel ke sel yang lain.

Kelompok bakteri endofit genus Monococcus memiliki manfaat juga bagi tanaman dalam membantu produksi enzim glutamylaminotransferase untuk membuat dan mengangkut karbon dan nitrogen dari mitohondria kebagian lain dari sel untuk membantu proses-proses metabolism sel.

Hidrogen peroksida $\left(\mathrm{H}_{2} \mathrm{O}_{2}\right)$ adalah hasil proses respirasi sel dan ini terjadi pada semua sel hidup. Selanjutnya karena $\mathrm{H}_{2} \mathrm{O}_{2}$ ini berbahaya bagi sel maka enzim katalase dihasilkan oleh sel untuk dapat mengkatalis $\mathrm{H}_{2} \mathrm{O}_{2}$. Oleh karena itu katalase berfungsi sebagai enzim peroksidase, terutama dalam reaksi dekomposisi untuk merubah hydrogen peroksida menjadi oksigen dan air (Nanda et al., 2017). Katalase dapat mengoksidasi satu molekul hydrogen peroksida pertama menjadi oksigen, dan kemudian kembali mereduksi satu molekul hydrogen peroksida kedua untuk menjadi air. Hal ini menyebabkan katalase berperan penting dalam mekanisme pertahanan sel terhadap oksidator hydrogen peroksida. Secara umum reaksi ini dapat berlangsung dengan baik apabila ada senyawa pemberi ion hydrogen seperti methanol, etanol dan formaldehida. Fungsi katalase didalam mengkatalis $\mathrm{H}_{2} \mathrm{O}_{2}$ adalah relatif kecil dibandingkan dengan kecepatan proses pembentukannya. Oleh karena itu sel-sel yang mengandung katalase sedikit, akan sangat lambat dalam mengatasi pengaruh peroksida.

Bakteri Streptococcus menghasilkan asam laktat ketika memecahkan glukosa pada jalur glikolisis (Saraswati et al., 2004). Proses fermentasi asam laktat berlangsung dalam dua cara, yaitu pertama melalui proses homofermentatif dimana hasil akhir sebagian besar merupakan asam laktat, dan kedua melalui proses heterofermentatif dengan hasil akhir adalah asam laktat, asam asetat, etanol dan $\mathrm{CO}_{2}$. Asam laktat yang dihasilkan melalui proses homofermentatif, biasanya dijumpai pada baketri Streptococcus, Pediococcus dan Lactobacillus (Altaf et al., 2008). Bakteri yang mengandung asam laktat biasa memiliki kemampuan untuk merombak bahan organik atau humus tanah, sehingga menjadi sumber unsur hara yang dapat diserap dengan mudah oleh akar tanaman. Selain itu bakteri demikian juga dapat mensterilkan tanah dari mikroorganisme penyebab penyakit seperti jamur fusarium dan nematode, dan dapat pula menghilangkan efek residu dari bahan-bahan yang 
tidak dapat terdekomposisi dengan baik seperti gas metan dan amonia yang bersifat racun bagi tanaman.

Bakteri Streptococcus juga menghasilkan anti bakteri berupa asam organik, dan bakteriosin yang mampu membunuh atau menghambat bakteri patogen, metabolit primer, hidrogen peroksida, diasetil, karbondioksida, asetaldehid dan juga dapat mengurangi $\mathrm{pH}$ lingkungannya melalui cara menghasilkan senyawa yang dapat menghalangi perkembangan bakteri patogen (Usmiati, 2012). Selanjutnya dikemukakan pula bahwa pada pupuk organik cair SO-Kontan dapat meningkatkan produksi padi lebih tinggi, karena mengandung banyak mikroba pengurai karbon organik, yaitu bakteri Streptococcus. Pupuk organik cair SO-Kontan banyak dipakai terutama untuk konservasi tanah, karena sangat baik sebagai media paling subur bagi pertumbuhan dan perkembangan mikroba pengurai bahan organik tanah. Selain itu bakteri Streptoccocus juga berfungsi sebagai pengurai karbon organik, sehingga $\mathrm{C} / \mathrm{N}$ ratio tanah menjadi kecil. Jika ratio $\mathrm{C} / \mathrm{N}$ tanah kecil maka tanah menjadi subur dan sifat fisik tanah terutama struktur tanah akan menjadi lebih baik. Bakteri Streptococcus yang terdapat dalam pupuk cair dapat pula berperan sebagai pengikat air, karena bakteri ini biasanya menempati daerah diferensiasi pada akar, sehingga ikut membantu pengaturan penyerapan air dan hara bagi tanaman.

\section{KESIMPULAN}

1. Terdapat 20 isolat bakteri endofit yang diisolasi dari 24 sampel jaringan akar dan daun pohon kayu marsegu (Anthocephalus cadamba), ketapang hutan (Terminalia copelandii) dan kayu burung (Elaeocarpus ganitrus).

2. Berdasarkan identifikasi makroskopis terhadap 20 isolat bakteri endofit, hanya diperoleh 11 isolat yang memiliki karakteristik yang berbeda. Selanjutnya pengujian karakteristik mikroskopis terhadap 11 isolat bakteri endofit dengan pendekatan metode pewarnaan gram dijumpai 3 kelompok bakteri yang hidup pada jaringan akar dan daun pohon kayu marsegu, ketapang hutan dan kayu burung, yaitu: genus Monococcus, Staphylococcus dan Streptococcus.

3. Bakteri endofit genus Monococcus ditemukan hidup pada semua jaringan akar dan daun pohon marsegu, ketapang hutan dan kayu burung. Sedangkan genus Streptococcus ditemukan hanya pada jaringan akar pohon kayu burung, tapi tidak ditemukan pada pohon kayu marsegu dan ketapang hutan. Kemudian genus Staphylococcus ditemukan pada jaringan akar pohon ketapang hutan dan jaringan daun pohon kayu marsegu, tetapi tidak ditemukan pada pohon kayu burung.

\section{DAFTAR PUSTAKA}

Altaf, M.D., B.J. Naveena, M. Venkateshwar, and E.V. Kumar. 2008. Amylolytic bacterial lactic acid fermentation. A Review. Biotechnology Advances 26: 22-34.

Hallman, J. and G. Berg. 2006. Spectrum and Population Dynamics of Bacterial Root Endophytes. Dalam: Schulz B, C. Boyle, and T. Sieber (Eds.). Soil biology Microbial Root Endophytes. Vol. 9. Berlin, Heidelberg, Germany, SpringerVerlag Holt JG., Krieg NR., Sneath PHA

Holt, J.G., P.H. Sneath, and N.R. Kreag. 1994. Bergey's Manual of Determinative Bacteriology. Ninth Ed. A Wolters Kluwer Company. Philadelphia. Hal 562-570.

Nanda, P.T., S.A. Siregar, R. Kurniawan, Hairuidin, Meriyanti, dan Yanto. 2017. Isolasi, karakterisasi dan uji potensi bakteri penghasil enzim termostabil air panas kerinci. Chempublish Journal 2: 26-31.

Pelczar, M.J. dan E.C.S. Chan. 1988. Dasar-Dasar Mikrobiologi. Terjemahan oleh Hadioetomo, R.S. Jakarta: Penerbit Universitas Indonesia.

Saraswati, R., T. Prihatini, dan R.D. Hastuti. 2004. Teknologi Pupuk Mikroba untuk Meningkatkan Efisiensi Pemupukan dan Keberlanjutan Sistem Produksi Padi Sawah. p. 169-189.

Stone, J.K., C.W. Bacon, and J.F. White Jr. 2000. An Overview of Endophytic Microbes: Endophytism Defined. New York: Marcel Dekker Inc.

Strobel, G. and B. Daisy. 2003. Bioprospecting for microbial endophytes and their natural products. Microbiology and Molecular Biology Reviews 67: 491-502.

Usmiati, S.R. 2012. Pengembangan dadih sebagai pangan fungsional probiotik asli Sumatra Barat. Jurnal Litbang Pertanian 32: 20-29. 